PETER C. HANEY

\title{
Fantasía and Disobedient Daughters Undistressing Genres and Reinventing Traditions in the Mexican American Carpa
}

During the 1930s and 1940s, female performers in Mexican American tent shows in San Antonio modified the costumes associated with Mexican "folkloric" dances, incorporating elements derived from vaudeville, to form a hybrid style called fantasía. This style asserted Mexican American identity while subverting the purist nationalism of folklórico dances and marking the performers' entry into newly public female roles. At the same time, it also involved the performers in reified masculinist discourses of female beauty and fashion.

THE SPANISH WORD FANTASIA CAN DENOTE fantasy, vanity, imagination, a whim, a caprice, or costume jewelry. As used by some artistas ("performers") of the Mexican American carpa ("tent show") in the 1930s and 1940s, the word acquired a more specialized meaning related to all of these. ${ }^{1}$ It referred to a style of clothing that emerged when performers playfully manipulated the "traditional" women's costumes associated with Mexican folklórico dances, giving them a gaudy, sexy, and irreverent flair. Fantasía costumes formed an "invented tradition" (Hobsbawm 1983) that reveled in its own glittery inventedness. As hybrids of folklórico and vaudeville, they were prime examples of the flamboyant aesthetic of bricolage that Tomás Ybarra-Frausto (1991) has called rasquachismo. By juxtaposing these genres, the performers negotiated their way through discourses of nationalism, sexuality, fashion, beauty, and shame which exerted both constraining and generative influences on their agency. My account of fantasía draws on surviving photographs of costumes used in the carpas and my own interviews with artistas who are pictured in those photographs. These performers spoke to me in terms that resonated with academic discussions of hybridity and modernity. Taking this ethnographic dialogue as a starting point, then, my analysis examines fantasía in ways that necessarily blur the traditional boundary between emic and etic categories of analysis. I aim to treat the concept not as a "native category" to be understood or explained in relation to existing theories but as a theoretical construct that can be brought into productive dialogue with other theories.

Peter C. Haney is a Ph.D. candidate in the Center for Intercultural Studies in Folklore and Ethnomusicology at the University of Texas at Austin 
The discussions of hybridity in this issue tend to focus either on hybridity in the Bakhtinian sense as a property of utterances, as a property of syncretic cultural traditions, or even as a property of individuals of mixed ethnic or "racial" heritage. Many of the commentators (e.g., Gordon and Anderson this issue; Samuels this issue) rightly criticize accounts of hybridity that reify genres, cultures, and identities or which fail to account for the historical and social locations of particular discourses of hybridity (e.g., Hale this issue). While these points are well taken, I would argue that the example of fantasía clearly shows how the concept of hybridity helps us to understand the ways in which social actors construct and deconstruct the boundaries between genres and between the discursive fields associated with them. The performers who used fantasia costumes were conscious of mixing genres, and they did so in a way that highlighted this transgression. Importantly, my consultants have explained this transgression to me not as a kind of "Americanizing" but as the "modernizing" of a Mexican tradition. For this reason, I have found ideas of syncretism less useful for understanding this phenomenon than the Bakhtinian view, which draws our attention to the combination and interillumination of socially distinguished sign systems.

\section{From Folklórico to Fantasía}

In order to understand fantasía, it is necessary to recall briefly the history of the folklórico form itself. Susan Stewart has noted that "distressed genres," or artificially antiqued expressive forms that appeal to an imagined and cherished past, often appear in "periods when nostalgia is juxtaposed with upheaval, revolution, and cultural distress" (1991:25). This phrase aptly describes the revolutionary Mexico from which the construction of folk dance as part of a nationalist cultural patrimony emerged. Under the auspices of Mexico's Secretariat of Public Education (SEP), dances collected by rural teachers were assembled into a canon, staged in prestigious theaters in the capital, and taught to public school students all over the country. Spread by government-run misiones culturales ("cultural missions"), which taught nationalism much as the Franciscans before them had taught Christianity, official folk dance presented a paradoxical view of lo mexicano ("Mexicanness") by offering a series of regional alterities (i.e., dances that showcased the distinctiveness of Jalisco, Chiapas, Oaxaca, Veracruz, etc.) as evidence of a unitary national identity. Like many expressions of nationalism, folklórico portrayed and portrays the present "in the guise of a pastness that is not necessarily a faithful sign of historical memory but a strategy of representing authority in terms of the artifice of the archaic" (Bhabha 1994:35).

Above all, promoters of folklórico have understood themselves as purists in search of the national soul's unsullied essence, and in their writings they have seldom used the word hibrido with positive connotations. For example, Carlos Mérida, in a discussion of the mixing of Spanish and indigenous traditions in Mexican dance, refers to this mixture as "fecund-never hybrid" (1990:181, my translation). Although Mérida does not develop this distinction in a rigorous way, it is clear that a "hybrid" mixture is a sterile and stigmatized one, more a pollution than an enrichment. Of course, this strategy of purity is partly informed by Mexico's geopolitical position. While folklórico dance has served as a hegemonic tool for Mexico's ruling class, it has also formed part of a counterhegemony in its role as a buffer against the cultural imperialism of the 
United States. This latter function remains especially important in the Mexican American context, in which folklórico, like so many other aspects of Mexico's official culture, has helped to bolster an enclaved Mexicano identity defined in opposition to the dominant Anglo-American society (Nájera-Ramírez 1989:28).

In addition to their official uses, official folk dances found wide audiences in the greater Mexican teatro de género chico ("popular theater") and the carpas (NájeraRamírez 1989:20), but in these settings the dances shed the seriousness of the statesponsored festivals. Adherence to strictly defined forms was simply not in the character of the popular stage. Juxtaposed with ribald jokes and political asides, the prettified pastoralism of folklórico dance reduced itself to cheerful absurdity. In some cases, the result was a saccharine tourist spectacle whose appeal to Mexican audiences was short-lived. As Covarrubias has noted, "The possibilities of the denatured folklore music and dances were quickly played out and the public very soon grew tired of nationalism" (1939:22). In other cases, such as that of the carpa, the dances gained back some of the carnivalesque character that official stagings had bled out of them. Whatever the result, purist critics and academics warned against "the danger of this picturesque-ism which cheapens the national culture by selling a hybrid and embarrassing product" (Mendoza 1990:23, my translation). Even María y Campos (1989), the great historian of the frivolous theater, saw the hybridity of this theater as its mortal flaw. Where "pure" tragedies and comedies will never die, he argues, "fundamentally hybrid genres, formed of disparate elements, are condemned irremissibly to die" because "their life must be as brief and fleeting as the fashion that created them" (1989:379, my translation). There is no denying, of course, that the "product" was unashamedly commercial and tied to fashion. The popular theater was show business, after all. There, commodified, distressed "folk dances" found a home in which their commodification could be frankly and gracefully acknowledged-and sometimes subverted. These stagings drew attention to the mass character of official folk dance and the blurring and interpenetration of cultural levels that Canclini (1992) sees as a defining feature of Latin American modernity.

This was also the case in San Antonio's Carpa García. As in many other tent shows, the Garcías used folklórico extensively, often opening their shows with chorus lines based on such dances. But, like their contemporaries in Mexico, they found their audiences losing interest in the genre. The Garcías' response was fantasía. My primary consultant on this phenomenon has been Esther García Robinson, a former acrobat and singer with the Carpa García. Born in 1921, Mrs. Robinson began participating in her father's show at the age of four and enjoyed a long artistic career in the carpa and later in the Cole Brothers' and Ringling Brothers' Circuses. In a 1990 interview, Mrs. Robinson drew an analogy for me between fantasía and the parodies of popular songs that her brother Rodolfo, a comedian, used to end his stage act. "From a real, single song," she stated, "they make a parodia ... then, from a real outfit, we go into modern and change it around." 2 Unlike parodies, however, the costumes were not seen as making fun of "traditional" ones so much as elaborating on them and "modernizing" them. Nevertheless, some of the features Mrs. Robinson described as fantasía exaggerate and relativize the picturesque quaintness of folklórico, giving the costumes a self-satirical edge. 
hybridity opens up the possibility of accounting for the socially situated choices of performers:

This act is not appropriation pure and simple. The vendor did not erase the tradition from this phrase in her revoicing of it; rather, she deliberately drew upon all of the meanings inherent in it, while adding another important semantic "tone" of her own-one that jarringly reversed the usual hierarchy of meanings present therein. [1993:316]

It is in this sense that I apply the term hybridity to fantasía. As in the above example, fantasía did not erase the nationalism of folklórico. Instead it gave that nationalism a "modern" accent by revoicing it in terms of an eclectic Mexicano popular theater that drew inspiration from similar forms all over the industrialized world. Thus, fantasía was one of many responses to a modernist and capitalist drive for innovation. It answered this drive by interpreting folklórico dance according to the logic of fashion and by embracing the commodity form in all its transitoriness.

\section{Carpa, Teatro, and Social Change}

This phenomenon can only be understood in relation to the sweeping and often violent social transformation that occurred in southern Texas during the early 20th century. From the beginning of the 20th century to the 1930s, commercial farming dominated by Anglo settlers progressively replaced the older ranching economy. Although ranching had also been Anglo-dominated after 1848, the transition to farming introduced drastic changes in productive relations and led to the growth of localized "Jim Crow" segregation for people of Mexican heritage (Montejano 1987: 159-161). Native-born Tejanos were forced to become wage laborers, and new immigrants fleeing the poverty and chaos of revolutionary Mexico added to their numbers. Drawn by the prospect of better paying jobs and an escape from rural discrimination, Mexicanos began to migrate in large numbers to Texas cities such as San Antonio and Houston (Montejano 1987:217). The industrialization associated with World War II was another important cause of this increasingly rapid urbanization of the Tejano population, which had already begun in the 1930s (Peña 1985:124-125). By the 1930s, Mexican American women had begun to participate in the ranks of wage laborers in unprecedented numbers, always facing double discrimination on account of their gender and ethnicity (Calderón and Zamora 1990:31). In the 1940s, World War II industrialization attracted many Mexicanos into new occupations in the cities. There, cultural and generational tensions inevitably surfaced.

One of the most important effects of this process was a sharpening of class divisions among Mexicanos, especially in San Antonio, the home base of many carpa companies. According to García, the 1930s "served to separate and crystallize the Mexican community of San Antonio into three distinct classes-a small Mexican bourgeoisie, a developing Mexican petit bourgeoisie, and a vast Mexican working class" (1978:24). During this time, the two venues of carpa (the tent shows) and teatro (the "legitimate" Spanish-language theater) served as important sites for the symbolic construction of class identities. My consultants' comments suggest to me that the expatriate Mexican elite and the emergent Mexican American middle class played a significant role in 
defining the ambiance and tenor of the theater, while the working class defined that of the carpa. On the prewar Spanish-language stage, a purist and nostalgic aesthetic of mexicanidad ("Mexicanness") associated with the ricos ("rich") had coexisted uneasily with a playful, distinctly Mexican American bilingual and bicultural sensibility associated with the middle class and the workers.

This class politics influenced the norms of proper behavior in the various theatrical venues. In interviews, artistas associated with carpa and teatro alike have repeatedly used the word respeto ("respect") to describe such norms. For Mexicanos, this single term invokes core ethical and interactive values of decency, gentility, politeness, deference, and "the responsible sense of self and others" (Limón 1994:110), and it is and was frequently used to encode class-bound concepts of civility. In the theaters, artistas showed their respect for the respetable público ("respectable audience") by speaking "correct" Spanish and exercising a certain patrician restraint in the use of sexual and scatological vocabulary. ${ }^{6}$ Audiences in the theaters were expected to show a corresponding respect toward the performers by dressing well and remaining quietly in their seats. Ramírez, in her study of Spanish-language dramatic companies in Texas, notes that theater reviews in Spanish-language newspapers as early as the second decade of the 20th century deployed the language of respeto to scold audiences who whistled, sang along with songs, and talked loudly during theater performances (1990:16).

In the carpa, such behavior was less stigmatized. As Ybarra-Frausto has observed, "The carpa tradition bonded the spectators and the spectacle in a nexus of social interaction" (1984:46). There, audiences engaged the performers in a raucous exchange of insults, wisecracks, and even sexual advances, cheering acts they enjoyed and booing (or worse) for what they did not. It would be a mistake to assume, however, that the norms of respeto, especially those relating to obscene words and sexual content, were without their influence in the carpa. Indeed, the widespread fear of "bad influences" caused hostility toward the form itself in some of the small towns that the Carpa García visited. This stigma was due both to the carpa's association with the working class and to the fact that some tent shows did indeed present raunchy, ribald entertainments. Criticism of the carpa focused particularly on female performers, whose behavior was seen as constitutive of a given show's moral caliber. Mrs. Robinson remembered a negative example:

There were some shows, you know, where the girls used to go into town and make the cantinas and all that, other shows, you know. Because in some towns, they locked the girls from one show, and they burn those towns, and then when a good family goes in there, they wouldn't let you in. That was . . along the [Rio Grande] Valley, where these girls from this show went out with some boys from the town, and they lock 'em in. So they didn't want nothing like that. . . . So my mother and daddy never allowed that. ... If you wanted to drink, you had to do it in your trailer and then go to sleep.

Here, Mrs. Robinson took pains to distinguish her own show from those whose casts drank, fought, and got locked up in prison. But the distinction between "a quiet, family show business" like the Garcías' and those that presented "bad influences" was sometimes lost on towns who had been "burned" by rowdy artistas. In any case, like female performers in many other patriarchal societies, the carperas faced a damning 
double bind. On the one hand, they were required to be beautiful and to display their bodies on stage as objects of desire. On the other, they were expected to be "respectable" and were reviled for going too far in their self-display. Of course, the very stigma that Mrs. Robinson described here may have influenced her depiction of her family's show. My concern here is not to establish exactly how squeaky-clean the Carpa García was but to examine the social conditions in which it operated and the Garcías' use of hybrid aesthetic forms to affect those conditions.

What is intriguing about Mrs. Robinson's narrative is that she presented sexual prudery as an "old-fashioned" value that Mexican American performers of her generation struggled against. Although she continuously asserted that the Carpa García lived within community norms, she also provided a counternarrative, in which her sister Consuelo initiated a "modern" movement away from restraint beginning in the mid-1930s:

In the old days, they used to wear just stockings, and they would not even stretch, because in the old days they had nothing like that. But, in the old days, they had to cover up because of these families. They wouldn't go and see the show. The Carpa Cubana, they used to cover their stomach with a cloth the color of the skin. But my sister, when the time came that we had to change, my sister says, "That's it. The stockings have to go. We're going to have to make my own makeup." [Wrinkly, restrictive mallas ("stockings") were replaced with a pigment made from albayalde ("white lead") and carmín ("cochineal").] Then the Carpa Cubana, they took their stockings off also. The owner did not like it because she was a very strict lady. She didn't like obscene things, you know. It was the old days. But my sisters would go out and work in their show, and they would come out without stockings, and she would go like this, you know [crosses herself]. ... They [the audience] would applaud them because they looked so modern. Their legs looked like doll's, you know. And then they [the Carpa Cubana's dancers] would come out with the wrinkled knees and all that, and they "BOO" to them.... When they would come out, their panza ["belly"] would look all wrinkled like this. The cloth was the color of the skin, but nevertheless [trails off]. They come in Hawaiian outfits, you know, to do opening number, but they didn't look nice because their stomach was covered.

There is no way to evaluate for sure Mrs. Robinson's claim that her family's company was on the cutting edge of "modern" innovative entertainment while other shows lagged behind. The Carpa Cubana, which was active in San Antonio and southern Texas during the 1920s and 1930s (Kanellos 1990:102), was a competitor of the Garcías, and her account may bear the residue of that relationship.

Whatever the progression may have been in the carpas, the theaters in San Antonio had been drawing crowds with the bataclán, a French-derived vaudeville act featuring dancers in bikini-like costumes, since the later years of the second decade of the 20th century (Kanellos 1990:79-80). It is possible that the carpas, catering as they did to a rural audience, may have moved more slowly than the urban theaters in the direction of making female costumes more revealing. Although the difference between the standards of the early 20 th century and those of the present day is clearly marked, the movement seems not to have been unilinear or uniform across the various sectors of Mexican American popular theater. As is often the case with fashion, the changes "appear regular if we consider a relatively long historical duration, ... irregular if we reduce this duration, ... and anarchic up close" (Barthes 1983:295). What is clear is 
that the changes in women's theatrical costumes reflected in heightened form the growing involvement of Mexicanas on both sides of the border in fashion and consumer culture and the growth of a "generation gap." Historian Vicki Ruiz has ably documented the process by which young Mexicanas in Los Angeles clashed with their parents over personal appearance as they began to define their identities through commodities (1993:113). Similar processes occurred in Mexico City beginning in the 1920s, when young women's decisions to bob their hair inspired not only parental disapproval but also satirical musical revues with titles like "La tierra de las pelonas" ("Land of the Bald Women") (Museo Nacional de Culturas Populares 1984:129). Photographic and other evidence suggest that similar processes were under way among Mexicanas in San Antonio as well. ${ }^{7}$

As a subaltern discourse of modernity, fantasía is also linked to the emergence of the Mexicana singer-dancer-stage idol called the vedette. Carlos Monsiváis (1980) notes that, in the 1920s, a crisis of traditional gender roles occurred in Mexico, much as it did north of the border. In this context, the vedette emerged as a female public figure, and it was this public character that made her novel. Although she remained the reified object of voyeuristic contemplation, she carved out a status for herself within those limitations that fit none of the existing models of femininity. She was neither fallen whore, nor blessed virgin, nor suffering mother, but "the inaccessible woman for those who lack money and power, whom they entrust with playing the Accessible and Dazzling Woman" (Monsiváis 1980:41, my translation). Her public presence lived in stage performances and inscribed itself indelibly on the public consciousness through photographs and picture postcards (Monsiváis 1980:39). This photographic existence was a type of "writing" that, importantly, was accessible to the nonliterate.

The female performers of the Mexican American stage can be seen as forming the northern tip of a greater Mexican vedette phenomenon. Like those of their counterparts in Mexico, their images appeared on postcards and other promotional materials. This was even true in the humble carpas. The Carpa García, for instance, distributed postcards everywhere it traveled. In one surviving example, Esther Robinson poses outside the carpa with a striped serape wrapped tightly about her body and her hair bound up in ribbons. ${ }^{8}$ Unlike the "big time" vedettes, the carpa artistas' primary life was not in photographs but in the intimate and ludic environment of the tent show itself. In the costume that appears on the postcard, Mrs. Robinson sang couplets that called for the audience to sing the chorus and make kissing noises to the beat. Another important couplet, "Mirame" ("Look at Me"), served as the platform for an even more interactive performance (see Haney 1990:6-7). As she sang "Mírame, mírame, mírame ..." in the darkened tent, Mrs. Robinson used a hand mirror to reflect the blinding light of the spotlight onto the faces of men in the audience. This move turned the crowd's laughing attention away from the performer and toward the men, reflecting back the tactility of their longing gazes. ${ }^{9}$

By revealing their bodies on stage and talking back to their audiences, artists like Esther Robinson and her sisters asserted ownership of those bodies, "taking charge of their beauty and talents" and often confronting the jealousy and paternalism of their male partners and collaborators (Smith 1991:50). In the process, they mounted a challenge to received elite standards of decency and respeto. By openly sexualizing 
folklórico costumes, the carpa artistas found illegitimate uses for these commodified tools of legitimation. For all this, they were both loved and reviled, portrayed as demonesses of sin and "goddesses of a religion no one ever bothered to name" (Monsiváis 1980:42-43, my translation). By playing and experimenting with received "folkloric" forms while incorporating influences from European, Mexican, and Anglo American vaudeville and cinema, they asserted their identity as Mexicanas in an Anglo-dominated world while relativizing the very idea of pure genres, insular identities, and sacrosanct cultural patrimonies. The result was the kind of joyous bricolage that made the carpa form the inspiration of the later Chicano theater movement and the contemporary performance art of Guillermo Gómez-Peña (1993:22).

It would be a mistake to assume, however, that carpa and teatro provided women performers with a source of unqualified agency, for their actions were never outside of power. Even as they deployed discourses of female beauty and fashion against their elders and class enemies, the carpa artistas also "became caught up in the new forms of subjection" that these discourses implied (Abu-Lughod 1990:52). For the body of the vedette, like that of the cover girl, ultimately "is no one's body" (Barthes 1983:259), a mere parole to the langue of a reified but constantly changing masculinist ideal. Mrs. Robinson's comment that the audiences cheered the García sisters because their legs looked like dolls' legs reveals the degree to which an inanimate, mechanized standard of beauty had become a norm for women (Buck-Morss 1989:365). In San Antonio, this image had a racial dimension as well. The famous Beatríz "La Chata" Noloesca, for example, ultimately became a comedian rather than a vedette because of this dynamic. Audiences found her indigenous-looking facial features and husky build more amusing than alluring, and as she gained weight she was steered toward comedy rather than serious roles (Smith 1991:40). In the end, the carpa and teatro themselves would fall victim to the very changes they celebrated and the very mass media whose influences they incorporated. By the 1950s, television and film had rendered the rich Spanish-language entertainment scene in San Antonio commercially unviable. Some artistas continued to work in the new media, while others settled down to more ordinary jobs, still giving occasional performances for church benefits and other occasions.

\section{Postscript: Angels of History}

On the cover of the 26 July 1981 "San Antonio Style" section of the San Antonio Express-News, Consuelo García and her sister Esther strut jauntily toward the camera and into the future, dressed in the finery of a show business gone by (see Figure 2). Consuelo's black charro costume recalls the mythical rancho ("ranch/countryside") of Mexican film, while Esther's billowing slitted gown, glittering beaded fringes, and Day-Glo "Az-tech" feathers invoke an Indian past that never was. Behind them, at the corner of Guadalupe and Brazos, lies the wreckage of a once-vibrant Spanish-language theater scene, now 30 years dead. The Guadalupe Theater has become a flea market, and the surrounding buildings show signs of wear and disrepair: Son los golpes que da la vida [Those are the blows live gives you]. "Progress" tears down what it builds, and one gets by as one can. Still fabulous and funky after all these years, Consuelo and Esther continue to look and move forward while the camera looks backward. Their 


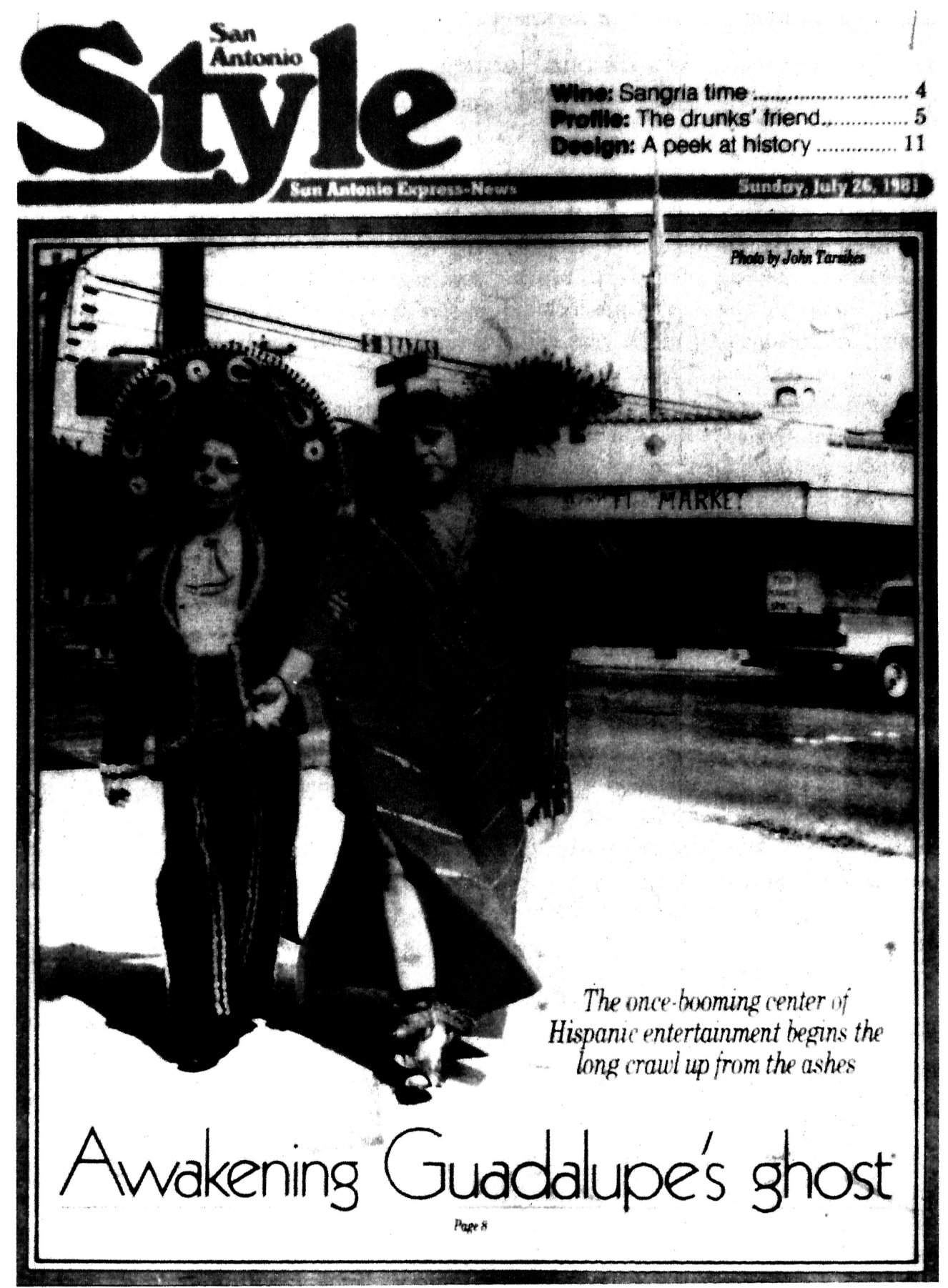

Figure 2. Consuelo and Esther García in 1981. Photograph courtesy of the San Antonio Express-News and Rudy García. Used by permission.

appearance in the Express-News lent the stamp of tradition to the efforts of a new generation of Chicano activists and artists who were building what would become the Guadalupe Cultural Arts Center out of this ruin. Today, the center is a nationally known arts organization and a major recipient of funding from the city of San Antonio and private foundations. Although its activities appeal to a wide and ever-expanding audience, the center has found its most solid base of support among middle-class Mexicanos in San Antonio who look to the West Side barrio as a source of cultural 
identity and authenticity. "Awakening Guadalupe's Ghost," says the headline (King 1981). Thus assimilated to a discourse of heritage - and now made an ethnographic example in my article-fantasía itself has become the original. ${ }^{10}$

\section{Notes}

I thank Grinnell College's Rosenfield Program in Public Affairs, International Relations, and Human Rights for its generous financial support of my fieldwork in 1990 and the University of Texas Institute of Texan Cultures at San Antonio for its institutional support during the same time. I also thank Jorge Piña and Rudy "Diamond" García of the Guadalupe Cultural Arts Center for assisting me in the field and Deborah Kapchan, José Limón, Manuel Peña, Marcia Stephenson, Christine Labuski, Maribel García, and Anne Johnson for their comments on earlier drafts of this article.

${ }^{1}$ I use the term Mexican American to refer to the carpa because the performers belonged to a political generation that applied this term to itself. Elsewhere in the article, I use Mexicano and Mexicana to refer to people of Mexican heritage in general, Mexican to refer to those born or living in Mexico, and Mexican American to refer to those born or living in the United States. I use Chicano to refer to aesthetic and political movements that have taken this name on as a term of struggle.

${ }^{2}$ All narratives are transcribed from tape PH90-3-1:3, on file at the University of Texas Institute of Texan Cultures at San Antonio.

${ }^{3}$ Known to American audiences as the Mexican Hat Dance, el jarabe tapatio is an official version of the jarabe, a type of popular dance common in various parts of Mexico. The official jarabe, which became standardized early in this century, is a couple dance, with the man dressed as a charro and the woman as a china poblana. The charro costume is derived from extravagantly decorated suits that were once used by wealthy Mexican ranchers. The historical origins of the china poblana costume are in debate, but the costume is intended to evoke an outgoing, colorful, rural femininity.

${ }^{4}$ The original rural costumes that served as the inspiration for the charro suits that mariachi musicians wear varied considerably, and many of them lacked the feature of the buttons on the legs. Fantasia alludes to and elaborates on standardized costume types.

${ }^{5}$ During my fieldwork in 1990, Carlos Monsiváis and the late Amada Monsiváis provided me with a photograph of their children dancing the jitterbug on the stage of the Carpa Monsivais. A copy negative (\#90-571) is on file in the photographic archive of the University of Texas Institute of Texan Cultures at San Antonio.

"Speakers of Spanish use "respetable público" when English speakers would use "ladies and gentlemen."

${ }^{7}$ I refer here both to photographs in the Hertzberg Collection, mentioned above, and to those I collected during my 1990 fieldwork, which are on file at the photography archive at the University of Texas Institute of Texan Cultures at San Antonio.

${ }^{8}$ The serape is a woolen shawl-like garment that men in some parts of Mexico wear around their shoulders. It has been made into a strong nationalist symbol, and Mrs. Robinson's use of it was quite pointed.

'Ybarra-Frausto (1984:46) includes an audience member's description of a similar act performed by another show.

${ }^{10}$ This conclusion was inspired in part by Benjamin's ninth thesis on the philosophy of history (1968: 257-258).

\section{References Cited}

Abu-Lughod, Lila. 1990. The Romance of Resistance: Tracing Transformations of Power through Bedouin Women. American Ethnologist 17:41-55.

Bakhtin, Mikhail M. 1981. The Dialogic Imagination, ed. Michael Holquist; translated by Caryl Emerson and Michael Holquist. Austin: University of Texas Press.

Barthes, Roland. 1983[1967]. The Fashion System. Translated by Matthew Ward and Richard Howard. New York: Hill and Wang. 
Benjamin, Walter. 1968. Theses on the Philosophy of History. In Illuminations, ed. Hannah Arendt, pp. 253-264. New York: Schocken Books.

Bhabha, Homi K. 1994. The Location of Culture. London: Routledge.

Buck-Morss, Susan. 1989. The Dialectics of Seeing: Walter Benjamin and the Arcades Project. Cambridge, Mass.: MIT Press.

Calderón, Roberto, and Emilio Zamora. 1990[1986]. Manuela Solís Sager and Emma Tenayuca: A Tribute. In Chicana Voices: Intersections of Class, Race and Gender, ed. Teresa Córdova, Norma Cantú, Gilberto Cárdenas, Juan Garcia, and Christine Siera, pp. 20-41. Albuquerque: University of New Mexico Press.

Canclini, Nestor García. 1992. Culturas híbridas: Estrategias para entrar y salir de la modemidad. Buenos Aires: Editorial Sudamericana, Colección Historia y Cultura.

Covarrubias, Miguel. 1939. Slapstick and Venom: Politics, Tent Shows, and Comedians. Mexican Life 15:21-59.

García, Richard A. 1978. Class Consciousness and Ideology-The Mexican Community of San Antonio, Texas: 1930-1940. Aztlán 9:23-70.

Gómez-Peña, Guillermo. 1993. Warrior for Gringostroika: Essays, Performance Texts, and Poetry. St. Paul, Minn.: Graywolf Press.

Haney, Peter. 1990. The Carpa in Texas. Unpublished report, University of Texas Institute of Texan Cultures at San Antonio.

Hobsbawm, Eric. 1983. Introduction: Inventing Traditions. In The Invention of Tradition, ed. Eric Hobsbawm and Terence Ranger, pp. 1-14. Cambridge and New York: Cambridge University Press.

Kanellos, Nicolás. 1990. A History of Hispanic Theater in the United States: Origins to 1940. Austin: University of Texas Press.

Kapchan, Deborah. 1993. Hybridity and the Marketplace: Two Emerging Paradigms in Folkloristics. Westerm Folklore 52:303-326.

King, Ben. 1981. Awakening Guadalupe's Ghost. San Antonio Express-News, San Antonio Style section, July 26: 8 .

Limón, José E. 1994. Dancing with the Devil. Madison: University of Wisconsin Press.

María y Campos, Armando de. 1989. Las tandas del principal. Mexico, D.F.: Editorial Diana.

Mendoza, Cristina. 1990. Introducción. In Escritos de Carlos Mérida sobre el arte: La danza, ed. Cristina Mendoza, pp. 13-37. Mexico, D.F.: Segunda Época, Serie Investigación y Documentación de las Artes. Mérida, Carlos. 1990. La danza en México. In Escritos de Carlos Mérida sobre el arte: La danza, ed. Cristina Mendoza, pp. 177-189. Mexico, D.F.: Segunda Época, Serie Investigación y Documentación de las Artes. Monsiváis, Carlos. 1980. Escenas de pudor y liviandad. Mexico, D.F.: Editorial Grijalbo.

Montejano, David. 1987. Anglos and Mexicans in the Making of Texas, 1836-1986. Austin: University of Texas Press.

Museo Nacional de Culturas Populares. 1984. El país de las tandas: Teatro de revista 1900-1940. Mexico, D.F.: Museo Nacional de Culturas Populares, Subsecretaria de Cultura.

Nájera-Ramírez, Olga. 1989. Social and Political Dimensions of Folklórico Dance. Westerm Folklore 48: 15-32.

Peña, Manuel. 1985. The Texas-Mexican Conjunto: History of a Working-Class Music. Austin: University of Texas Press.

Ramírez, Elizabeth. 1990. Footlights across the Border: A History of Spanish-Language Professional Theater on the Texas Stage. New York: Peter Lang Publishing.

Ruiz, Vicki L. 1993. "Star Struck": Acculturation, Adolescence, and the Mexican American Woman, 1920-1950. In Building with Our Hands: New Directions in Chicana Studies, ed. Adela de la Torre and Beatríz Pesquera, pp. 109-129. Berkeley: University of California Press.

Smith, Pamela Ann. 1991. Beatríz Noloesca La Chata: An Oral History. Master's thesis, Anthropology Department, University of Texas at Austin.

Stewart, Susan. 1991. Notes on Distressed Genres. Joumal of American Folklore 104:5-31.

Ybarra-Frausto, Tomás. 1984. I Can Still Hear the Applause. La farándula Chicana: Carpas y tandas de variedad. In Hispanic Theater in the United States, ed. Nicolás Kanellos, pp. 45-60. Houston: Arte Público Press. 